\title{
BIOSYNTHETIC STUDIES OF ARPHAMENINES A AND B
}

\author{
Shokichi Ohuchi, Akira Okuyama, Hiroshi Naganawa, \\ TAKAAKi AOYAGI and HaMaO UMEZAWA \\ Institute of Microbial Chemistry, 3-14-23 Kamiosaki, Shinagawa-ku, Tokyo 141, Japan \\ (Received for publication January 6, 1984)
}

\begin{abstract}
The biosynthetic pathways of arphamenines A and B were studied. Arphamenine A was derived from acetic acid, L-arginine and L-phenylalanine, and arphamenine B from acetic acid, L-arginine and L-tyrosine.
\end{abstract}

As reported in our previous papers ${ }^{1,2)}$, two potent aminopeptidase $\mathrm{B}$ inhibitors, arphamenines $\mathrm{A}$ and $\mathrm{B}$ were found in the culture filtrates of Chromobacterium violaceum BMG361-CF4. Their structures were determined to be 5-amino8-guanidino-4-oxo-2-phenylmethyl octanoic acid (A) and 5-amino-8-guanidino-2-(4-hydroxyphen-

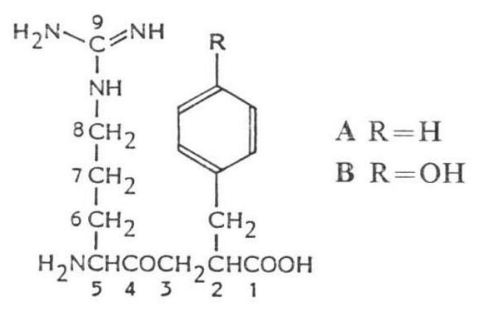
ylmethyl)-4-oxo-octanoic acid (B), respectively.

To study the biosynthetic precursors of these compounds, ${ }^{14} \mathrm{C}$-labeled acetate, L-arginine, Lphenylalanine and L-tyrosine were chosen for the radiolabeling experiments as they promoted production of arphamenines ${ }^{3)}$. The role of acetate as the source of the methylene ketone moiety $\left(-\stackrel{*}{\mathrm{C}} \mathrm{H}_{2}-\stackrel{* *}{\mathrm{C}}-\right)$ in arphamenines was examined, using sodium $\left.\left[1-{ }^{13} \mathrm{C}\right]\right]^{* *}$ acetate, sodium $\left[2-{ }^{13} \mathrm{C}\right] *$ acetate or sodium $\left[1,2{ }^{18} \mathrm{C}\right]$ acetate.

\section{Materials and Methods}

Isotope-labeled Compounds

L- $\left[U-{ }^{14} \mathrm{C}\right]$ Arginine $\quad(327.0 \mathrm{mCi} / \mathrm{mmol}), \quad$ L- $\left[\right.$ methyl $\left.l{ }^{14} \mathrm{C}\right]$ methionine $\quad(48.7 \mathrm{mCi} / \mathrm{mmol}), \quad$ L- $\left[U-{ }^{14} \mathrm{C}\right]-$ phenylalanine $(510.0 \mathrm{mCi} / \mathrm{mmol}), \mathrm{L}-\left[U_{-14} \mathrm{C}\right]$ tyrosine $(497 \mathrm{mCi} / \mathrm{mmol})$, sodium $\left[1-{ }^{14} \mathrm{C}\right]$ acetate $(56.0 \mathrm{mCi} /$ $\mathrm{mmol})$ and sodium $\left[2{ }^{14} \mathrm{C}\right]$ acetate $(51.0 \mathrm{mCi} / \mathrm{mmol})$ were purchased from New England Nuclear, U.S.A. Sodium $\left[2-{ }^{13} \mathrm{C}\right]$ acetate $(92.2 \%$ enrichment) was purchased from the British Oxygen Co. Ltd., England. DL- $\left[1-{ }^{14} \mathrm{C}\right]$ Arginine $(35 \sim 45 \mathrm{mCi} / \mathrm{mmol})$, sodium $\left[1-{ }^{13} \mathrm{C}\right]$ acetate $(90 \%$ enrichment $)$ and sodium $\left[1,2-{ }^{13} \mathrm{C}\right]-$ acetate ( $90 \%$ enrichment) were purchased from Commissarat a L'Energie Atomique, France.

Assay of Anti-aminopeptidase B Activity

Inhibition of aminopeptidase B activity of rat liver by arphamenines was determined as reported previously ${ }^{4}$.

Incorporation of Radioactivity into Arphamenines

Cells of $C$. violaceum BMG361-CF4 previously grown on KRAINSKY's asparagine glucose agar slants were incubated in $110 \mathrm{ml}$ of a medium consisting of $3 \%$ soluble starch, $0.5 \%$ Prorich (Ajinomoto Co.), $1.2 \%$ corn gluten meal and $0.2 \% \mathrm{CaCO}_{3}$, in a $500-\mathrm{ml}$ Erlenmeyer flask for 20 hours at $27^{\circ} \mathrm{C}$ on a rotary shaker (180 rpm). After inoculation of $0.5 \mathrm{ml}$ of the seed culture thus prepared into the same medium (110 ml, $\pm 1 \%$ L-phenylalanine), the incubation was carried out as before. ${ }^{14} \mathrm{C}$-Labeled compounds at $10 \mu \mathrm{Ci}$ (except DL-[1- $\left.{ }^{14} \mathrm{C}\right]$ arginine, $20 \mu \mathrm{Ci}$ ) were added at the times indicated in Table 1 and the biosynthetic experiments were continued for 4 hours. 
Fig. 1. Production of arphamenine A by $C$. violaceum BMG361-CF4.

Medium: Soluble starch $3 \%$, Prorich $0.5 \%$, corn gluten meal $1.2 \%$, L-Phe $1.0 \%, \mathrm{CaCO}_{3} 0.2 \%$.

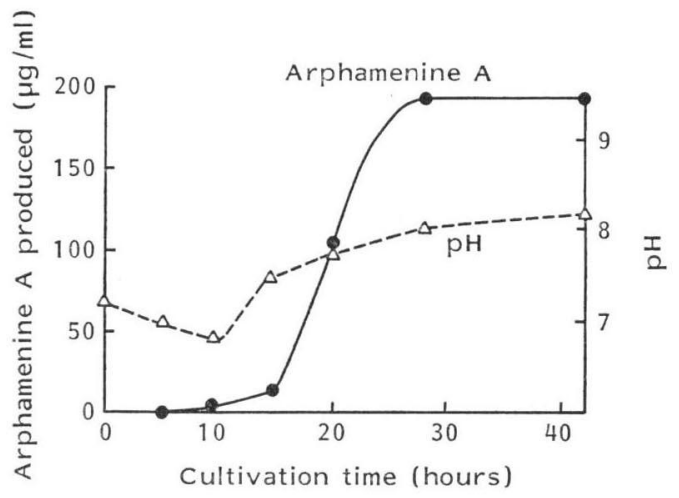

Table 1. Incorporation of ${ }^{14} \mathrm{C}$-labeled compounds into arphamenines.

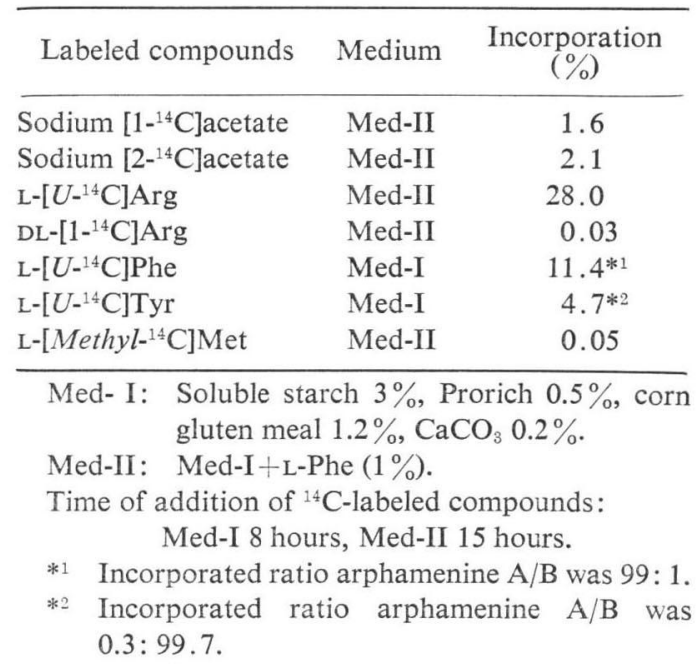

Twenty $\mathrm{ml}$ of culture filtrate were chromatographed on a column of CM-Sephadex C-25 (20 ml) which was developed with $0.5 \mathrm{M} \mathrm{NaCl}$. Fractions containing arphamenines were combined (25 ml). Five-tenth $\mathrm{ml}$ of the combined solution was applied to a TLC plate of silica gel (E. Merck, Art5721) and developed with the solvent system: butanol - acetic acid - water (4:1:1) or chloroform - methanol acetic acid - water (10:4:1:1). Arphamenines were visualized with $0.4 \%$ solution of ninhydrin in acetone. The area containing the arphamenines was cut out from the plate and transferred to vials for counting. Eight $\mathrm{ml}$ of scintillation cocktail (Aquasol-2, New England Nuclear, U.S.A.) were added and the radioactivity of each sample was measured in a Beckman LS9800 liquid scintillation counter.

Preparation of ${ }^{13} \mathrm{C}$-Labeled Arphamenine A

After strain BMG361-CF4 was cultured in $110 \mathrm{ml}$ of the L-phenylalanine-containing medium for 15 hours, $50 \mathrm{mg}$ of sodium $\left[1-{ }^{13} \mathrm{C}\right]$ acetate, sodium $\left[2-{ }^{18} \mathrm{C}\right]$ acetate or sodium $\left[1,2-{ }^{13} \mathrm{C}\right]$ acetate plus $100 \mathrm{mg}$ of unlabeled sodium acetate and $110 \mathrm{mg}$ of L-arginine monohydrochloride were added. The incubation was continued for 4 hours.

One hundred $\mathrm{ml}$ of culture filtrate was chromatographed on a column of CM-Sephadex C-25 $(100 \mathrm{ml})$ which was developed with a linear gradient of $\mathrm{NaCl}$ from 0 to $0.5 \mathrm{M}$. Arphamenine A-containing fractions were combined and desalted on an Amberlite XAD-4 adsorption column; elution was carried out with 50\% aqueous acetone. The crude arphamenine A thus obtained was rechromatographed on CM-Sephadex C-25 using $0.2 \mathrm{M} \mathrm{NaCl}$ as eluant. The purified arphamenine A-containing fractions were subsequently desalted on a column of Sephadex LH-20: elution of ${ }^{13}$ C-labeled arphamenine A $(10 \sim 20 \mathrm{mg})$ was attained with water.

\section{${ }^{13} \mathrm{C}$ NMR Spectrometry}

Fourier-transform ${ }^{13} \mathrm{C}$ NMR spectra were obtained on a Jeol FX-200 NMR spectrometer operating at $50.1 \mathrm{MHz}$. Each sample was dissolved in $0.25 \mathrm{ml}$ of $\mathrm{D}_{2} \mathrm{O}$ and was run in a tube with 5 mm diameter at $25^{\circ} \mathrm{C}$. The running conditions were as follows: spectral width: $15 \mathrm{KHz}$, pulse width: $2.5 \mu$ seconds and repetition time: 1.73 seconds. Accumulations were as follows: 5,000 for arphamenine A (10 mg) labeled with $\left[1-{ }^{13} \mathrm{C}\right]$ acetate, 10,000 for arphamenine $\mathrm{A}(10 \mathrm{mg})$ labeled with $\left[2-{ }^{13} \mathrm{C}\right]$ acetate and 31,888 for arphamenine A (4.8 mg) labeled with $\left[1,2-{ }^{13} \mathrm{C}\right]$ acetate.

\section{Results and Discussion}

C. violaceum BMG361-CF4 produced only arphamenine A in a L-Phe-containing medium; production occurred at 15 hours as shown in Fig. 1. By contrast, in the same medium without L-phenylalanine, 
Table 2. ${ }^{18} \mathrm{C}$ NMR spectral data for arphamenine A, including enrichments from labeled precursors.

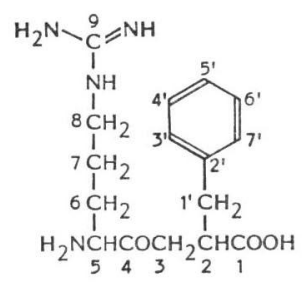

\begin{tabular}{|c|c|c|c|c|}
\hline \multirow{2}{*}{ Carbon No. } & \multirow{2}{*}{$\partial \mathrm{C}^{* 1}$} & \multirow{2}{*}{ Multiplicity*2 } & \multicolumn{2}{|c|}{ Enrichment factor*3 } \\
\hline & & & {$\left[1-{ }^{13} \mathrm{C}\right]$ Acetate } & {$\left[2-{ }^{13} \mathrm{C}\right]$ Acetate } \\
\hline 1 & 182.6 & $\mathrm{~s}$ & 0.48 & 0.64 \\
\hline 2 & 45.6 & $\mathrm{~d}$ & 0.50 & 0.74 \\
\hline 3 & 41.8 & $\mathrm{t}$ & 1.0 & 10.8 \\
\hline 4 & 207.2 & $\mathrm{~s}$ & 10.4 & 0.66 \\
\hline 5 & 58.9 & $\mathrm{~d}$ & 0.56 & 0.64 \\
\hline 6 & 26.8 & $\mathrm{t}$ & 0.59 & 0.72 \\
\hline 7 & 24.1 & $\mathrm{t}$ & 0.73 & 0.80 \\
\hline 8 & 41.1 & $\mathrm{t}$ & 0.74 & 1.20 \\
\hline 9 & 157.7 & s & 0.78 & 0.85 \\
\hline $1^{\prime}$ & 38.6 & $\mathrm{t}$ & 0.68 & 0.78 \\
\hline $2^{\prime}$ & 140.3 & $\mathrm{~s}$ & 1.00 & 1.00 \\
\hline $3^{\prime}, 7^{\prime}$ & 129.4 & $\mathrm{~d} \times 2$ & 0.75 & 0.84 \\
\hline $4^{\prime}, 6^{\prime}$ & 129.9 & $\mathrm{~d} \times 2$ & 0.84 & 0.94 \\
\hline $5^{\prime}$ & 127.3 & d & 0.66 & 0.76 \\
\hline
\end{tabular}

*1 In $\mathrm{D}_{2} \mathrm{O}$ (internal dioxane $\delta$ 67.4).

*2 Multiplicities in the off-resonance decoupling: s, singlet; d, doublet; $t$, triplet.

*3 Intensity of each peak in the labeled arphamenine A devided by that of the corresponding peak in the unlabeled arphamenine $\mathrm{A}$, normalized to give a ratio of 1.00 for the peak of $2^{\prime}-\mathrm{C}$.

Fig. 2. Building blocks for arphamenines $\mathrm{A}$ and $\mathrm{B}$.

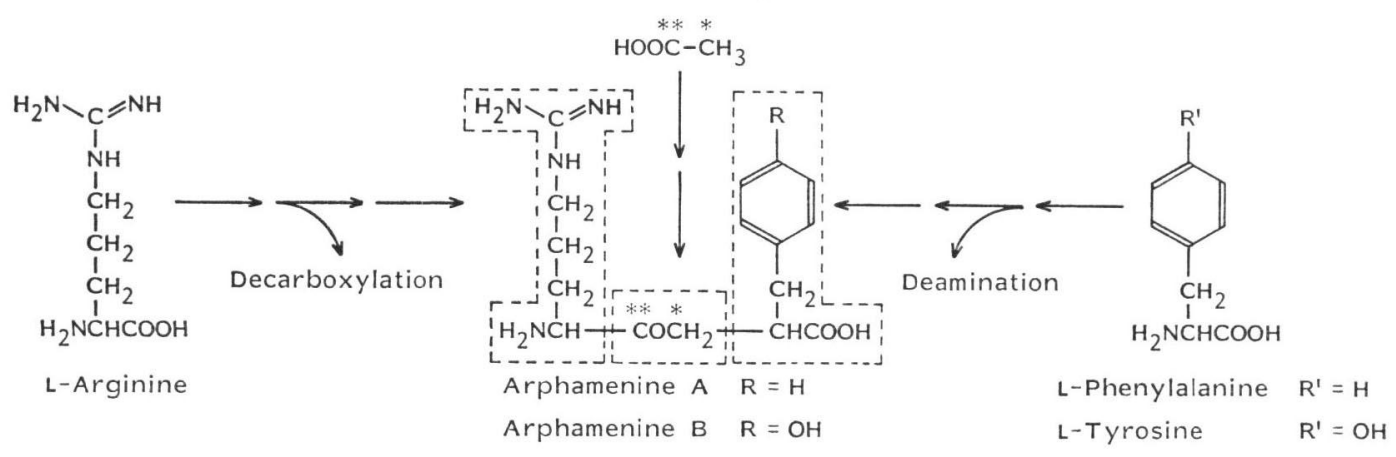

both arphamenines $\mathrm{A}$ and $\mathrm{B}$ production occurred at 8 hours. Thus, ${ }^{14} \mathrm{C}$-labeled compounds were added to the respective media at 8 and 15 hours.

As shown in Table 1, $\mathrm{L}-\left[\mathrm{U}-{ }^{14} \mathrm{C}\right]$ arginine, sodium $\left[1-{ }^{14} \mathrm{C}\right]$ acetate and sodium $\left[2-{ }^{14} \mathrm{C}\right]$ acetate were efficiently incorporated into arphamenine $\mathrm{A}$, whereas $\mathrm{DL}-\left[1-{ }^{14} \mathrm{C}\right]$ arginine and $\mathrm{L}-\left[\right.$ methyl- $\left.{ }^{14} \mathrm{C}\right]$ methionine were not incorporated to any significant extent. In addition, $\mathrm{L}-\left[U-{ }^{14} \mathrm{C}\right]$ phenylalanine was incorporated into arphamenine $\mathrm{A}$, but not appreciably into arphamenine B. On the other hand, $\mathrm{L}-\left[U-{ }^{14} \mathrm{C}\right]$ tyrosine was incorporated into arphamenine $\mathrm{B}$, but not into arphamenine $\mathrm{A}$. In both cases the ratio of incorpora- 
tion of radiolabel into the arphamenines A and B did not change during a further 16 hours' incubation after the addition of ${ }^{14} \mathrm{C}$-labeled compounds.

These experimental results indicated that the $N$-terminal moiety of arphamenines A and B was derived from L-arginine, the $C$-terminal moiety was derived from L-phenylalanine (arphamenine $\mathrm{A}$ ) and L-tyrosine (arphamenine B) and the methylene ketone $\left(-\stackrel{4}{\mathrm{C}} \mathrm{O}-\stackrel{3}{\mathrm{C}} \mathrm{H}_{2}-\right)$ moiety was derived from acetate.

In order to establish the distribution of radiocarbon from acetate, ${ }^{13} \mathrm{C}$-labeled arphamenine $\mathrm{A}$ was prepared with sodium $\left[1-{ }^{13} \mathrm{C}\right]$ acetate, sodium $\left[2-{ }^{13} \mathrm{C}\right]$ acetate or sodium $\left[1,2-{ }^{13} \mathrm{C}\right]$ acetate. As shown in Table $2,{ }^{13} \mathrm{C}$ NMR spectra of ${ }^{13} \mathrm{C}$-labeled arphamenine $\mathrm{A}$ enriched with sodium $\left[1-{ }^{13} \mathrm{C}\right]$ acetate and sodium $\left[2-{ }^{13} \mathrm{C}\right]$ acetate indicated that the enrichment of ${ }^{13} \mathrm{C}$ occurred only at $\mathrm{C}-4$ or $\mathrm{C}-3$, respectively. ${ }^{13} \mathrm{C}$ NMR spectra of ${ }^{13} \mathrm{C}$-labeled arphamenine $\mathrm{A}$ enriched with sodium $\left[1,2-{ }^{13} \mathrm{C}\right]$ acetate also indicated the spin coupling between $\mathrm{C}-3\left(\mathrm{~J}_{\mathrm{c}-\mathrm{c}}=44 \mathrm{~Hz}\right)$ and $\mathrm{C}-4 *$.

From the results of our experiments, the building blocks for arphamenines are L-arginine, L-phenylalanine or L-tyrosine and acetic acid, as shown in Fig. 2. The fact that $\mathrm{L}-\left[U_{-}{ }^{14} \mathrm{C}\right]$ phenylalanine was only incorporated into arphamenine A whereas $L-\left[U_{-}{ }^{14} \mathrm{C}\right]$ tyrosine was only incorporated into arphamenine $\mathrm{B}$ suggests that arphamenine $\mathrm{A}$ is not converted to arphamenine $\mathrm{B}$.

In a subsequent paper, we will report on the complete biosynthetic pathway to arphamenines ${ }^{5)}$.

\section{Acknowledgment}

This work was partly supported by a contract from the Division of Cancer Treatment, National Cancer Institute, NO1-CM-57009, U.S.A.

\section{References}

1) Umezawa, H.; T. Aoyagi, S. Ohuchi, A. Okuyama, H. Suda, T. Takita, M. Hamada \& T. Takeuchi: Arphamenines A and B, new inhibitors of aminopeptidase B, produced by bacteria. J. Antibiotics 36: $1572 \sim 1575,1983$

2) Ohuchi, S.; H. Suda, H. Naganawa, T. Takita, T. Aoyagi, H. Umezawa, H. Nakamura \& Y. Iitaka: The structure of arphamenines A and B. J. Antibiotics 36: 1576 1580, 1983

3) Ohuchi, S.; A. Okuyama, K. Kawamura, T. Aoyagi \& H. Umezawa: The improvement of productivity and selective production of arphamenines. Agric. Biol. Chem. 48(6): 1984, in press

4) Umezawa, H.; T. Aoyagi, H. Suda, M. Hamada \& T. TAKeuchi: Bestatin, an inhibitor of aminopeptidase B, produced by actinomycetes. J. Antibiotics 29: 97 99, 1976

5) Okuyama, A.; S. Ohuchi, T. Tanaka, T. Aoyagi \& H. Umezawa: Cell-free biosynthesis of arphamenine A. in preparation.

* $\quad J_{\mathrm{c}-\mathrm{c}}$ was not determined by overlapping of other signal (C-8). 